\title{
Influence of Fertility and Mowing Height on Performance of Established Centipedegrass
}

Joe E. Toler

Department of Applied Economics and Statistics, F-148 Poole Agricultural Center, Clemson University, Clemson, SC 29634-0375

Jason K. Higingbottom and Lambert B. McCarty ${ }^{1}$

Department of Horticulture, E-143 Poole Agricultural Center, Clemson University, Clemson, SC 29634-0319

Additional index words. Eremochloa ophiuroides, turfgrass color, turfgrass coverage, turfgrass quality

\begin{abstract}
Centipedegrass [Eremochloa ophiuroides (Munro) Hack.] is widely grown throughout the southeastern United States as a low-maintenance turfgrass; however, limited peer-reviewed research is available on "best" cultural practices for established centipedegrass. This research was conducted to examine the long-term effects of mowing height and fertility regimens providing various rates and application times of soil-applied granular $F e$ and $N$ on centipedegrass quality and surface coverage. Soil type was a Cecil sandy loam (clayey, kaolinitic, thermic Typic Hapludult) with a pH of 5.5. A mowing height of $3.8 \mathrm{~cm}$ was equal to or better than the $1.9 \mathrm{~cm}$ mowing height throughout the study. The rate of $\mathrm{N}$ fertilization played an important role in achieving optimal turfgrass quality and coverage with the two highest rates $\left(97.6\right.$ and $\left.195.2 \mathrm{~kg} \cdot \mathrm{ha}^{-1} \mathrm{~N}\right)$, generally providing similar results when applied as split applications in May and August and mowed at $3.8 \mathrm{~cm}$. These treatments provided turfgrass quality ratings of 8.3-9.0, turfgrass color ratings of 8.1-8.7, and turfgrass coverage of $94 \%$ to $98 \%$ over a 3 -year period. The addition of soil-applied Fe sulfate at a rate of $24.4 \mathrm{~kg} \cdot \mathrm{ha}^{-1} \mathrm{Fe}$ was not beneficial to centipedegrass performance or color. Results indicate that the addition of $97.6 \mathrm{~kg} \cdot \mathrm{ha}^{-1} \mathrm{~N}$, using split-applications in May and August and a mowing height of $3.8 \mathrm{~cm}$ for established centipedegrass, should achieve acceptable turfgrass quality and coverage.
\end{abstract}

Centipedegrass [Eremochloa ophiuroides] is a popular turfgrass grown in the southeastern United States from North Carolina to Florida and along the Gulf Coast to Texas, yet limited published research is available on "best" cultural practices for established centipedegrass. It is a slow growing, naturally yellow-green grass with medium leaf texture that typically exhibits iron (Fe)-deficiency symptoms (Beard, 1973). Centipedegrass is a general-purpose turfgrass that requires little fertilizer, infrequent mowing, and grows best in full sun to moderate shade; however, it does not tolerate heavy traffic, compaction, drought, or high-phosphorus soils very well (Johnson and Burns, 1985). Centipedegrass provides a low-maintenance turfgrass needing to be mowed only every $10-14 \mathrm{~d}$ at a recommended range of $2.5-5 \mathrm{~cm}$ (McCarty, 2003).

Although centipedegrass requires little maintenance, it must receive proper nutrition to maintain adequate growth (Johnson et al., 1988). Centipedegrass generally responds well to nitrogen $(\mathrm{N})$ fertilization, but the amount and timing are crucial to avoid the

Received for publication 7 Nov. 2006. Accepted for publication 23 Jan. 2007.

${ }^{1}$ To whom reprint requests should be addressed; e-mailbmccrty@clemson.edu. spring occurrence of weak to dead grass termed "centipedegrass decline" (Johnson and Carrow, 1988). Centipedegrass decline is associated with excessive thatch, leaving stolons susceptible to cold temperatures and desiccation. Excessive $\mathrm{N}$ fertilization may enhance color and growth but contributes to centipedegrass decline problems. Low $\mathrm{N}$ fertilization may result in pale green color and poor growth.

Most turfgrasses, including centipedegrass, are sensitive to $\mathrm{Fe}$ applications and generally respond by developing a darkergreen color, especially in alkaline soils or soils high in P content (Sartain, 1999). It is known that $\mathrm{Fe}$ is required by plants to make chlorophyll, and this helps explain the foliage color response to $\mathrm{Fe}$ applications and also why centipedegrass grows better on acidic soils where $\mathrm{Fe}$ is more available (Brady and Weil, 2004). Carrow et al. (1988) reported that foliar $\mathrm{Fe}$ applications at low rates (1.5 and $2.2 \mathrm{~kg} \cdot \mathrm{ha}^{-1}$ ) improved plant color but contributed to increased phytotoxicity of centipedegrass when applied to turfgrass receiving relatively low $\mathrm{N}$ rates $\left(12.2\right.$ and $24.4 \mathrm{~kg} \cdot \mathrm{ha}^{-1}$ ).

The objectives of this research were to examine the effects of both soil-applied $\mathrm{N}$ and $\mathrm{Fe}$ on established centipedegrass quality and density when applied alone or in combination using single or split applications and to assess whether mowing height affects centipedegrass response to the fertility treatments.

A 3-year field study was conducted in the summers of 2000, 2001, and 2002 at the Clemson Univ. Turfgrass Research Facility in Clemson, SC. The study site was established from sod in May of 1999 on a Cecil sandy loam (clayey, kaolinitic, thermic Typic Hapludult) soil with $6 \%$ to $10 \%$ slope and pH 5.5. Mehlich III extractable soil phosphorus level was $47 \mathrm{~kg} \cdot \mathrm{ha}^{-1}$, and no fertilizer was applied before initiation of the study. Extractable soil phosphorus level was categorized into the medium acceptable range of 11.2$67.2 \mathrm{~kg} \cdot \mathrm{ha}^{-1}$ (McCarty, 2005). Irrigation was applied twice weekly (as needed) to provide $2.54 \mathrm{~cm}$ of water per week.

A $2 \times 10$ factorial experiment was used to examine the effects of two mowing heights $(1.9$ and $3.8 \mathrm{~cm})$ and 10 fertility regimens using various rates and application times of $\mathrm{N}$ and $\mathrm{Fe}$ (Table 1). Mowing was performed every $7 \mathrm{~d}$ throughout the growing season at actual set heights using a rotary-type mower, and clippings were returned. $\mathrm{N}$ fertilization was provided by a granular $16 \mathrm{~N}-1.7 \mathrm{P}-6.6 \mathrm{~K}$ commercial fertilizer (TriCounty Fertilizer and Specialty Co., Honea Path, S.C.) with equal amounts of soluble urea and insoluble polymer sulfur-coated urea. Fe fertilization was provided by a granular $20 \%$ soluble Fe derived from Fe sulfate (Southern Agricultural Insecticides, Hendersonville, N.C.). Fertilizers were applied with hand-held shaker cans using multiple passes in different directions to achieve uniform distribution and watered-in immediately with $6.4 \mathrm{~mm}$ of water.

Visual ratings of centipedegrass shoot coverage (not rated in 2000), quality, and color were made every 2 weeks throughout each growing season. Turfgrass quality ratings were on a 1-10 scale with 1 denoting no live grass, 7 denoting minimal acceptable, and 10 denoting best turfgrass quality. Turfgrass color ratings were on a 1-10 scale with 1 denoting brown grass and 10 denoting uniform, dark green color. Turfgrass coverage ratings were on a $0 \%$ to $100 \%$ scale, with $0 \%$ denoting no grass or surface coverage and $100 \%$ denoting complete, uniform dense grass.

A split-block (strip plot) experimental design (Kuehl, 2000) arranged in three randomized complete blocks was used to conduct the factorial experiment. Each block consisted of two randomly assigned mowing height whole plots stripped across 10 randomly assigned fertilizer regimen whole plots. Intersections of the perpendicular whole plots provided subplots that measured $2 \times 2 \mathrm{~m}$ and were used to evaluate interaction between the factors. Analysis of variance was performed to evaluate main and interaction effects of the two factors and determine whether treatment effects were consistent across sampling dates and years using a general linear models procedure (SAS Institute, 2005). The multiple comparisons with the best (MCB) procedure (Hsu, 1984) were used to identify "best" treatments. 


\begin{tabular}{|c|c|c|c|c|c|c|c|}
\hline \multirow{2}{*}{ Mowing ht $(\mathrm{cm})$} & \multicolumn{4}{|c|}{ Fertilizer regimen } & & & \\
\hline & \multicolumn{2}{|c|}{$\mathrm{N}$} & \multicolumn{2}{|c|}{$\mathrm{Fe}$} & \multicolumn{3}{|c|}{ Turfgrass quality $(1-10)^{\mathrm{z}}$} \\
\hline \multirow[t]{7}{*}{$\overline{1.9}$} & 0.0 & - & 0.0 & - & 5.9 & 6.3 & 5.4 \\
\hline & 48.8 & May + Aug. & 0.0 & - & 6.3 & 7.2 & 6.9 \\
\hline & 48.8 & May & 0.0 & - & 6.2 & 7.4 & 7.0 \\
\hline & 97.6 & May + Aug. & 0.0 & - & 6.4 & 8.1 & 7.6 \\
\hline & 195.2 & May + Aug. & 0.0 & - & 6.8 & $8.7 *$ & 7.8 \\
\hline & 24.4 & Aug. & 24.4 & May & 5.8 & 6.4 & 5.8 \\
\hline & 0.0 & - & 48.8 & May + Aug. & 5.7 & 6.4 & 4.8 \\
\hline \multirow[t]{6}{*}{3.8} & 0.0 & - & 0.0 & - & 7.5 & 6.8 & 5.5 \\
\hline & 24.4 & May & 0.0 & - & 8.0 & 7.5 & 7.1 \\
\hline & 48.8 & May + Aug. & 0.0 & - & 7.9 & 7.3 & 6.6 \\
\hline & 48.8 & May & 0.0 & - & 7.9 & 7.5 & 6.9 \\
\hline & 97.6 & May + Aug. & 0.0 & - & $8.3^{*}$ & 8.3 & 8.3 \\
\hline & 0.0 & - & 48.8 & May + Aug. & 7.6 & 6.9 & 6.0 \\
\hline
\end{tabular}

${ }^{\mathrm{z}}$ Turfgrass quality rated every 2 weeks on a $1-10$ scale $(1=$ all grass dead and $10=$ optimal turfgrass quality $)$ and averaged across growing season; treatment by rating date interaction was not detected. Ratings were averaged across multiple rating dates during the growing season.

y"May + Aug." denotes split applications with one-half of $\mathrm{N}$ applied each time.

*Means within a column are selected by the MCB procedure, with $P=0.95$, so that the "best" treatment is included.

This procedure selects treatments into a subset such that the "best" treatment is included with $P=0.95$.

\section{Results}

Due to significant treatment $\times$ year interactions $(P<0.01)$, results were examined separately for each year. However, because no meaningful treatment $x$ date interactions were detected $(P>0.05)$, results were combined across rating dates each year for evaluation of treatment effects.
Year 1 (2000). No mowing height $\times$ fertilizer regimen interaction was observed for centipedegrass quality in $2000(P>0.05)$, but main effects of each factor were detected $(P<0.001$; Table 1$)$. Turfgrass quality was greatly affected by mowing height as ratings averaged 6.1 and 7.9 for the 1.9 and $3.8 \mathrm{~cm}$ mowing heights, respectively; thus, the low mowing height resulted in unacceptable $(<7)$ turfgrass quality in 2000. Increasing the $\mathrm{N}$ level resulted in linear increases in turfgrass quality $(P<0.001)$, while the addition of granular $\mathrm{Fe}$ did not affect turfgrass quality. In 2000, the "best" turfgrass quality was achieved with either 97.6 or $195.2 \mathrm{~kg} \cdot \mathrm{ha}^{-1} \mathrm{~N}$, using split applications in May and August and mowed at $3.8 \mathrm{~cm}$, as these treatments received visual quality ratings of 8.3 and 8.6, respectively.

No mowing height $\times$ fertilizer regimen interaction or main effect of mowing height was observed for centipedegrass color $(P>$ $0.05)$, but main effects of fertilizer were detected $(P<0.001$; Table 2$)$. Increases in $\mathrm{N}$ level resulted in linear increases in turfgrass color $(P<0.001)$, while application of granular Fe did not affect turfgrass color $(P>$ 0.05). In 2000, the "best" turfgrass color was

Table 2. Effects of mowing height and fertilizer regimen on centipedegrass color, 2000-2002.

\begin{tabular}{|c|c|c|c|c|c|c|c|}
\hline \multirow[b]{3}{*}{ Mowing ht $(\mathrm{cm})$} & \multicolumn{4}{|c|}{ Fertilizer regimen } & & & \\
\hline & \multicolumn{2}{|c|}{$\mathrm{N}$} & \multicolumn{2}{|c|}{$\mathrm{Fe}$} & \multicolumn{3}{|c|}{ Turfgrass color $(1-10)^{\mathrm{z}}$} \\
\hline & Rate $\left(\mathrm{kg} \cdot \mathrm{ha}^{-1}\right)$ & Timing $^{\mathrm{y}}$ & Rate $\left(\mathrm{kg} \cdot \mathrm{ha}^{-1}\right)$ & Timing $^{\mathrm{y}}$ & 2000 & 2001 & 2002 \\
\hline \multirow[t]{10}{*}{1.9} & 0.0 & - & 0.0 & - & 6.7 & 7.3 & 6.9 \\
\hline & 24.4 & May & 0.0 & - & 7.5 & 7.9 & 7.6 \\
\hline & 48.8 & May + Aug. & 0.0 & - & 7.6 & 7.6 & 7.3 \\
\hline & 48.8 & May & 0.0 & - & 7.5 & 7.8 & 7.7 \\
\hline & 97.6 & May + Aug. & 0.0 & - & $8.1^{*}$ & 8.3 & 8.3 \\
\hline & 195.2 & May + Aug. & 0.0 & - & $8.1^{*}$ & $8.8^{*}$ & $8.7 *$ \\
\hline & 24.4 & May & 24.4 & Aug. & 7.5 & 7.3 & 7.0 \\
\hline & 48.8 & May & 24.4 & Aug. & 7.4 & 7.3 & 7.4 \\
\hline & 24.4 & Aug. & 24.4 & May & 7.1 & 7.2 & 7.3 \\
\hline & 0.0 & - & 48.8 & May + Aug. & 7.3 & 7.7 & 7.3 \\
\hline \multirow[t]{10}{*}{3.8} & 0.0 & - & 0.0 & - & 6.9 & 7.0 & 6.2 \\
\hline & 24.4 & May & 0.0 & - & 7.8 & 7.6 & 7.3 \\
\hline & 48.8 & May + Aug. & 0.0 & - & 7.6 & 7.3 & 7.1 \\
\hline & 48.8 & May & 0.0 & - & 7.8 & 7.6 & 7.3 \\
\hline & 97.6 & May + Aug. & 0.0 & - & $8.3^{*}$ & 8.1 & 8.3 \\
\hline & 195.2 & May + Aug. & 0.0 & - & $8.5^{*}$ & $8.7^{*}$ & $8.7 *$ \\
\hline & 24.4 & May & 24.4 & Aug. & 7.5 & 7.0 & 6.6 \\
\hline & 48.8 & May & 24.4 & Aug. & 7.8 & 7.1 & 7.4 \\
\hline & 24.4 & Aug. & 24.4 & May & 7.2 & 6.8 & 6.8 \\
\hline & 0.0 & - & 48.8 & May + Aug. & 7.5 & 7.5 & 7.0 \\
\hline
\end{tabular}

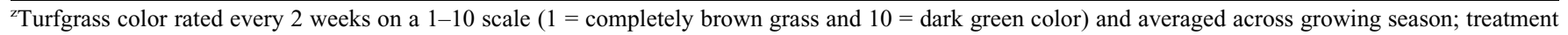
by rating date interaction was not detected. Ratings were averaged across multiple rating dates during the growing season.

y"May + Aug." denotes split applications with one-half of N applied each time.

*Means within a column are selected by the MCB procedure, with $P=0.95$, so that the "best" treatment is included. 
achieved with either 97.6 or $195.2 \mathrm{~kg} \cdot \mathrm{ha}^{-1} \mathrm{~N}$, using split applications in May and August and mowed at either 1.9 or $3.8 \mathrm{~cm}$, as these treatments received visual color ratings that ranged from 8.1 to 8.5 .

Year 2 (2001). No mowing height $x$ fertilizer regimen interaction or main effect of mowing height was observed for centipedegrass quality or color $(P>0.05)$, but main effects of fertilizer were detected $(P<0.01$; Tables 1 and 2). Increases in $\mathrm{N}$ level resulted in linear increases in turfgrass quality and color $(P<0.001)$, while application of granular $\mathrm{Fe}$ did not affect turfgrass quality or color $(P>0.05)$. In 2001, the "best" turfgrass quality and color were achieved with $195.2 \mathrm{~kg} \cdot \mathrm{ha}^{-1} \mathrm{~N}$, using split applications in May and August and mowed at either 1.9 or $3.8 \mathrm{~cm}$, as these treatments received visual quality and color ratings $>8.5$.

No mowing height $\times$ fertilizer regimen interaction was observed for centipedegrass shoot coverage $(P>0.05)$, but main effects of each factor were detected $(P<0.05$; Table 3$)$. Shoot coverage was affected by mowing height as coverage averaged $80 \%$ and $86 \%$ for the 1.9 and $3.8 \mathrm{~cm}$ mowing heights, respectively. Increases in $\mathrm{N}$ level resulted in linear increases in shoot coverage $(P<$ $0.001)$, while the addition of granular $\mathrm{Fe}$ did not improve shoot coverage $(P>0.05)$. In 2001, the "best" turfgrass shoot coverage was obtained with $97.6 \mathrm{~kg} \cdot \mathrm{ha}^{-1} \mathrm{~N}$, using split applications in May and August and mowed at $3.8 \mathrm{~cm}$, and with $195.2 \mathrm{~kg} \cdot \mathrm{ha}^{-1} \mathrm{~N}$, using split applications in May and August and mowed at either 1.9 or $3.8 \mathrm{~cm}$, as these treatments achieved excellent coverage levels of $94 \%, 95 \%$, and $94 \%$, respectively.

Year 3 (2002). No mowing height $x$ fertilizer regimen interaction or main effect

Table 3. Effects of mowing height and fertilizer regimen on centipedegrass density, 2001 and 2002.

\begin{tabular}{|c|c|c|c|c|c|c|}
\hline \multirow[b]{3}{*}{ Mowing ht (cm) } & \multicolumn{4}{|c|}{ Fertilizer regimen } & & \\
\hline & \multicolumn{2}{|c|}{$\mathrm{N}$} & \multicolumn{2}{|c|}{$\mathrm{Fe}$} & \multicolumn{2}{|c|}{ Turfgrass coverage $(\%)^{*}$} \\
\hline & Rate $\left(\mathrm{kg} \cdot \mathrm{ha}^{-1}\right)$ & Timing $^{y}$ & Rate $\left(\mathrm{kg} \cdot \mathrm{ha}^{-1}\right)$ & Timing $^{y}$ & 2001 & 2002 \\
\hline \multirow[t]{10}{*}{1.9} & 0.0 & - & 0.0 & - & 70 & 65 \\
\hline & 24.4 & May & 0.0 & - & 87 & 88 \\
\hline & 48.8 & May + Aug. & 0.0 & - & 85 & 86 \\
\hline & 48.8 & May & 0.0 & - & 84 & 87 \\
\hline & 97.6 & May + Aug. & 0.0 & — & 91 & 92 \\
\hline & 195.2 & May + Aug. & 0.0 & - & $95^{*}$ & 91 \\
\hline & 24.4 & May & 24.4 & Aug. & 79 & 77 \\
\hline & 48.8 & May & 24.4 & Aug. & 79 & 80 \\
\hline & 24.4 & Aug. & 24.4 & May & 67 & 69 \\
\hline & 0.0 & - & 48.8 & May + Aug. & 69 & 62 \\
\hline \multirow[t]{10}{*}{3.8} & 0.0 & - & 0.0 & - & 83 & 68 \\
\hline & 24.4 & May & 0.0 & - & 91 & 89 \\
\hline & 48.8 & May + Aug. & 0.0 & - & 89 & 83 \\
\hline & 48.8 & May & 0.0 & - & 91 & 87 \\
\hline & 97.6 & May + Aug. & 0.0 & - & $94 *$ & $95^{*}$ \\
\hline & 195.2 & May + Aug. & 0.0 & - & $94 *$ & $98 *$ \\
\hline & 24.4 & May & 24.4 & Aug. & 86 & 79 \\
\hline & 48.8 & May & 24.4 & Aug. & 86 & 87 \\
\hline & 24.4 & Aug. & 24.4 & May & 71 & 67 \\
\hline & 0.0 & - & 48.8 & May + Aug. & 78 & 70 \\
\hline
\end{tabular}

${ }^{\mathrm{z}}$ Turfgrass coverage rated every 2 weeks on a $0 \%$ to $100 \%$ scale $(0 \%=$ no grass and $100 \%=$ complete, uniform dense coverage) and averaged across growing season; treatment by rating date interaction was not detected. Ratings were averaged across multiple rating dates during the growing season.

y"May + Aug." denotes split applications with one-half of $\mathrm{N}$ applied each time.

* Means within a column are selected by the MCB procedure, with $P=0.95$, so that the "best" treatment is included.

of mowing height was observed for centipedegrass quality, color, or shoot coverage $(P>$ $0.05)$, but main effects of fertilizer were detected for all three characteristics $(P<$ . quality and color $(P<0.001)$ and curvilinear responses in shoot coverage $(P<0.01$ for the quadratic term). Application of granular $\mathrm{Fe}$ did not affect any of the measured characterics $(P>0.05)$

In 2002, the "best" turfgrass quality was applications in May and August and mowed at $3.8 \mathrm{~cm}$, as this treatment received a visual quality rating of 9.0. The "best" turfgrass or in 2002 was achieved with $195.2 \mathrm{~kg} \cdot \mathrm{ha}^{-1}$ and mowed at either 1.9 or $3.8 \mathrm{~cm}$, as these treatments received visual color ratings of 8.7. The "best" turfgrass shoot coverage was obtained with either 97.6 or $195.2 \mathrm{~kg} \cdot \mathrm{ha}^{-1} \mathrm{~N}$ applications in May and Augus mowed at $3.8 \mathrm{~cm}$, as these treatments and $98 \%$, respectively.

\section{Discussion}

This study demonstrated that mowing height and $\mathrm{N}$ fertilization rate affect growth and quality of established centipedegrass turfgrass independently as no significant quality by the addition of granular Fe sulfate. Sartain (1999), in a comprehensive article on Fe utrition for turfgrasses, stated that soil are often marginal as ferrous converts to water-insoluble Fe in near- neutral to alkaline soil. Centipedegrass may be more responsive to foliar $\mathrm{Fe}$ applications as Carrow et al. (1988) and Carrow and Johnson (1990) achieved improved centipedegrass color with foliar rates of only 0.73 $\mathrm{kg} \cdot \mathrm{ha}^{-1} \mathrm{Fe}$. However, granular products are often desired by end users over liquid fertilizer formulations, which is the reason they were used in our study.

During this 3-year study, the $3.8 \mathrm{~cm}$ mowing height provided equal or higher turfgrass quality than did the $1.9 \mathrm{~cm}$ mowing height, and the highest $\mathrm{N}$ rate $\left(195.2 \mathrm{~kg} \cdot \mathrm{ha}^{-1}\right)$ generally provided better turfgrass quality than did lower $\mathrm{N}$ rates. Therefore, the combination of $3.8 \mathrm{~cm}$ mowing height and $195.2 \mathrm{~kg} \cdot \mathrm{ha}^{-1} \mathrm{~N}$, provided in split applications (May and August), was either the "best" treatment or in the "best" subset of treatments for achieving optimal turfgrass quality each year. Johnson and Carrow (1988) also found that split applications during the growing season provided equal or better centipedegrass quality than did a single yearly application of $100 \mathrm{~kg} \cdot \mathrm{ha}^{-1} \mathrm{~N}$ early in the growing season.

Centipedegrass color was influenced by fertility treatments each of the 3 years, but mowing height did not affect turfgrass color any year. Split applications of the two highest $\mathrm{N}$ rates $\left(97.6\right.$ and $195.2 \mathrm{~kg} \cdot \mathrm{ha}^{-1}$ ) provided optimal turfgrass color in the first year of the study, while the highest $\mathrm{N}$ rate resulted in the "best" color ratings in 2001 and 2002. Johnson et al. (1988) also reported enhanced centipedegrass color as the yearly $\mathrm{N}$ rate increased from 0 to $200 \mathrm{~kg} \cdot \mathrm{ha}^{-1}$ but noted that $200 \mathrm{~kg} \cdot \mathrm{ha}^{-1} \mathrm{~N}$ contributed to progressive centipedegrass decline symptoms over a 4-year period. Carrow et al. (1988) reported centipedegrass color responded to increasing $\mathrm{N}$ and foliar $\mathrm{Fe}$ rates with optimal color achieved with highest yearly rates $\left(39 \mathrm{~kg} \cdot \mathrm{ha}^{-1}\right.$ $\mathrm{N}$ and $3 \mathrm{~kg} \cdot \mathrm{ha}^{-1} \mathrm{Fe}$ ).

Centipedegrass shoot coverage was affected by mowing height and fertility treatments in each of the 2 years rated (2001 and 2002). Optimal shoot coverage was generally achieved with the $3.8 \mathrm{~cm}$ mowing height in combination with either of the two highest $\mathrm{N}$ rates $\left(97.6\right.$ or $195.2 \mathrm{~kg} \cdot \mathrm{ha}^{-1}$ ) each year. Miller et al. (1979) concluded that yearly $\mathrm{N}$ rates of 25 to $50 \mathrm{~kg} \cdot \mathrm{ha}^{-1}$ were sufficient to maintain healthy, dense centipedegrass, but other researchers have reported that much higher $\mathrm{N}$ rates are necessary to maintain acceptable centipedegrass quality. Johnson et al. (1988) in Georgia noted $100 \mathrm{~kg} \cdot \mathrm{ha}^{-1} \mathrm{~N}$ per year provided the best centipedegrass coverage, while researchers in Mississippi (Palmertree et al., 1974; Walker and Ward, 1974) and in central Florida (Pritchett and Horn, 1962) have recommended $\approx 200 \mathrm{~kg} \cdot \mathrm{ha}^{-1} \mathrm{~N}$. Thus, varying soil and environmental conditions may greatly impact the yearly $\mathrm{N}$ rate necessary to maintain acceptable centipedegrass coverage.

In summary, optimal turfgrass quality and coverage of established centipedegrass was generally achieved with yearly split applications of either 97.6 or $195.2 \mathrm{~kg} \cdot \mathrm{ha}^{-1} \mathrm{~N}$ and a mowing height of $3.8 \mathrm{~cm}$. However, as mentioned, 
Johnson and Carrow (1992) observed some problems with centipedegrass decline after 3 years of their long-term study when $>100 \mathrm{~kg} \cdot \mathrm{ha}^{-1} \mathrm{~N}$, was applied yearly. Although no centipedegrass decline was observed in this study, the lower $\mathrm{N}$ rate $\left(97.6 \mathrm{~kg} \cdot \mathrm{ha}^{-1} \mathrm{~N}\right)$ would probably be most practical in the long term. Use of soil-applied $\mathrm{Fe}$ was not found to benefit centipedegrass color or performance.

\section{Literature Cited}

Beard, J.B. 1973. Turfgrass: science and culture. Prentice-Hall, Inc., Upper Saddle River, N.J.

Brady, N.C. and R.R. Weil. 2004. Elements of the nature and properties of soils. 2nd ed. PrenticeHall, Inc., Upper Saddle River, N.J.

Carrow, R.N. and B.J. Johnson. 1990. Response of centipedegrass to plant growth regulator and iron treatment combinations. Appl. Agr. Res. 5:21-26.

Carrow, R.N., B.J. Johnson, and G.W. Landry, Jr. 1988. Centipedegrass response to foliar application of iron and nitrogen. Agron. J. 80:746-750.
Hsu, J.C. 1984. Constrained simultaneous confidence intervals for multiple comparisons with the best. Ann. Stat. 12:1136-1144.

Johnson, B.J. and R.E. Burns. 1985. Effect of sequential fertilizer and cultural treatments on centipedegrass (Eremochloa ophiuroides). Proc. 5th Int. Turfgrass Res. Conf. 5:505-514.

Johnson, B.J. and R.N. Carrow. 1988. The frequency of fertilizer applications and centipedegrass performance. Agron. J. 80:925-929.

Johnson, B.J. and R.N. Carrow. 1992. Influence of soil $\mathrm{pH}$ and fertility program on centipedegrass. Agron. J. 84:21-26.

Johnson, B.J., R.N. Carrow, and R.E. Burns. 1988. Centipedegrass decline and recovery as affected by fertilizer and cultural practices. Agron. J. 80:479-486.

Kuehl, R.O. 2000. Design of experiments: statistical principles of design and analysis. 2nd ed. Duxbury Press, Pacific Grove, Calif.

McCarty, L.B. 2005. Best golf course management practices. 2nd ed. Prentice-Hall, Inc., Upper Saddle River, N.J.

McCarty, L.B. 2003. Southern lawns-best management practices for the selection, establishment and maintenance of southern lawngrasses. Clemson Univ. Public Service Printing, Clemson, S.C. Miller, L.C., R.W. Miller, C.L. Parks, and C.S. Gorsuch. 1979. Centipedegrass and its problems. South Carolina Circ. 583.

Palmertree, H.D., C.Y. Ward, and R.H. Pluenneke. 1974. Influence of mineral nutrition on the cold hardiness and soluble protein fraction of centipedegrass. Proc. 2nd Int. Turfgrass Res. Conf. 2:500-507.

Pritchett, W.L. and G.C. Horn. 1962. Turfgrass fertilization research. Proc. Univ. Fla. Turfgrass Mgt. Conf. 10:209-215.

Sartain, J.B. 1999. Iron nutrition improves turfgrass's mettle. Grounds Maintenance [Online] 1 Aug. 1999. <http://grounds-mag.com/ mag/grounds_maintenance_iron_nutrition improves $/>$.

SAS Institute. 2005. The SAS system for Windows, v. 9.1. SAS Inst., Cary, N.C.

Walker, R.H. and C.Y. Ward. 1974. Influence of $\mathrm{N}$ and $\mathrm{K}$ nutrition on net photosynthesis, dark respiration, and carbohydrates in centipedegrass. Proc. 2nd Int. Turfgrass Res. Conf. 2:196-208. 